WIDER Working Paper 2018/78

\title{
Slack resources and innovation in Vietnamese SMEs
}

A behavioural, stewardship, and institutional perspective

Tam Thanh Nguyen ${ }^{1,2}$ and Chieu Duc Trinh ${ }^{1}$

August 2018

United Nations University World Institute for Development Economics Research

wider.unu.edu 
Abstract: Slack resources are usually identified as an endogenous motivation for firms' innovation. Still, it is crucial to assess the importance of slack in supporting innovation, especially in different institutional contexts. Therefore, the paper investigates the relationship by exploring a longitudinal dataset of 15,589 observations from about 2,500 surveyed manufacturing small and medium enterprises (SMEs) in Vietnam. The analysis reveals that slack resources promote innovation in different ways. While the financial slack harms the efforts of introducing innovation, the presence of human resource slack encourages firms to engage more in innovation activities resulting in the introduction of new products or business processes. We further found that for firms located in a more favourable business environment the impact of human resource slack on innovation is less pronounced whereas the negative impact of financial slack is lessened. The above results enrich the current literature on the relationship between slack and innovation within an institutional context in emerging economies.

Keywords: innovation, slack, stewardship theory, behavioural theory, institutional economics theory, emerging economy SMEs

JEL classification: O30, D02, D21

Acknowledgements: The authors thank Professor John Rand for his invaluable comments, and Thinh Nguyen for his assistance in preliminary data analysis.

${ }^{1}$ Central Institute for Economic Management, Ministry of Planning and Investment, Hanoi, Vietnam, corresponding author, email: tamnt@mpi.gov.vn; ${ }^{2}$ The University of Queensland Business School, The University of Queensland, Australia.

This study has been prepared within the UNU-WIDER project on 'Structural transformation and inclusive growth in Vietnam'.

Copyright (C) UNU-WIDER 2018

Information and requests: publications@wider.unu.edu

ISSN 1798-7237 ISBN 978-92-9256-520-6 https://doi.org/10.35188/UNU-WIDER/2018/520-6

Typescript prepared by Ans Vehmaanperä.

The United Nations University World Institute for Development Economics Research provides economic analysis and policy advice with the aim of promoting sustainable and equitable development. The Institute began operations in 1985 in Helsinki, Finland, as the first research and training centre of the United Nations University. Today it is a unique blend of think tank, research institute, and UN agency — providing a range of services from policy advice to governments as well as freely available original research.

The Institute is funded through income from an endowment fund with additional contributions to its work programme from Finland, Sweden, and the United Kingdom as well as earmarked contributions for specific projects from a variety of donors.

Katajanokanlaituri 6 B, 00160 Helsinki, Finland

The views expressed in this paper are those of the author(s), and do not necessarily reflect the views of the Institute or the United Nations University, nor the programme/project donors. 
Small and medium enterprises (SMEs) play an important role in socio-economic development. These firms provide a growth engine for the economies through creating jobs and supplying goods and services that are not provided by larger counterparts (Acs and Audretsch, 1990, 1993; Cunningham, 2011; Honjo and Harada, 2006; Storey, 1994). This sector accounts for more than 95 per cent of all firms and 60 per cent of employment in developed countries (OECD, 2000). They also contribute between half and three quarters of the value added in the OECD enterprise sector (Mazzarol, 2014). Especially in developing economies, the development of SMEs is crucial for society stabilization and poverty alleviation (Smallbone and Welter, 2001). The development of SMEs provides solutions for poor people to escape from poverty through attracting them to work or even to start an enterprise themselves (Beck et al., 2005; Bauchet and Morduch, 2013). Additionally, the SME sector helps to absorb economic shocks and natural and social disasters (Smallbone and Welter, 2001). In Viet Nam, according to the General Statistics Office (GSO, 2017), 98.7 per cent of operating enterprises are SMEs in terms of the number of employees and they hire around 60 per cent of the total labour force in the enterprise sector.

Despite their important role in economies and society, SMEs are now facing many challenges during their development that may prevent them from profitable operation, such as limited access to markets and customers, and difficulties in sustaining growth. The facts show that innovation provides an efficient tool for these firms to overcome these shortcomings (Cefis and Marsili, 2006). Through introducing new products, firms have advantages in the access to new markets and new customers (Hausman and Johnston, 2014). Meanwhile, the application of new business processes allows firms to reduce production costs and enrich the specifications of current products that enable firms to gain market share and sustain growth (Hall et al., 2009). However, common constraints for the innovation of SMEs-such as shortage of capital and lack of qualified staffprevent firms from investing in innovation activities that are as such risky and costly (Hadjimanolis, 1999; Madrid-Guijarro et al., 2009; Sandberg and Aarikka-Stenroos, 2014). The presence of slack resources might provide an efficient solution for firms to innovate.

There is extensive research on the role of slack resources on performance and innovation. Slack resources would equip firms with a buffer from resource shortages which provides sufficient capital for innovation activities (Cyert and March, 1963). The existence of slack resources also motivates firm owners/managers to search for business opportunities to fully utilize those unused resources, resulting in the introduction of new products, new processes or new markets (Penrose, 1959). However, possessing resource slack is not always associated with innovation (Nohria and Gulati, 1996). The possible interest difference/conflict between owners and managers drives managers to maintain excessive resources in the operation of firms, thus causing a resource waste in low-risk investments (Fama, 1980). Consequently, this discourages firms to innovate. In addition, too much slack occupies the required resources for innovation thus restricting the efforts of introducing new products (Tan and Peng, 2003).

A first possible explanation for the different influences of slack is the difference in business types. In family-run businesses where the benefits of the business are strongly connected with the welfare of family members, one of the owners/managers' priorities is to ensure the longevity of the firm, which in the long run benefits various family members (Gomez-Mejia et al., 2007). Consequently, this may prevent firms from using slack to finance firms' activities including innovation. This is different in large firms with well-organized structures where the managers are willing to deploy those excessive resources to meet the demands of the firm. 
Second, different types of slack have different impacts on innovation. Slack is different in terms of divisibility, tangibility and mobility (Mishina et al., 2004). Those differences in turn affect the ability of firms to exploit and deploy the slack for innovation activities (Wang et al., 2016). For instance, divisible slack is more easily mobilized to meet the resource demand of innovation activities, thus positively influencing the innovation of firms.

Another reason for the different directions and influences on firms' innovation is that slack resources do not work in isolation. The impact of slack resources depends on the combination with other external and internal innovation support factors that have been less understood (Marlin and Geiger, 2015). Extant research explores this relationship focusing on firms in developed countries, whereas in developing countries, the impact of slack resources may be more pronounced due to the less mature nature of both the capital and the labour market (ILO, 2016). Taken together, the heterogeneity across firms in different business environments/circumstances and the differences among types of slack challenge the impact of slack resources on innovation.

Therefore, in order to respond to these speculations, we ask two connected research questions. The first question is whether different types of slack resources improve innovation and the second question is how the institutional context strengthens or hinders the impact of slack resources on the innovation of firms. We investigate these two research questions through an exploration of a longitudinal dataset for Vietnamese SMEs. To do this, we first provide a brief literature review of innovation and slack resources, culminating in a research model and hypotheses. We then explain our data collection and methods and conclude with a discussion of our findings and possible theoretical and practical contributions.

\section{Conceptual background and hypothesis development}

\subsection{Innovation}

Innovation is well studied under the theme of economics and management (Schumpeter, 1939; Peters et al., 2017). Innovation involves a range of activities such as Research and Development (R\&D) and product delivery and occupies a large amount of financial and human resources with the final aim of introducing something new that potentially benefits the firm's operations and performance (Hogan et al., 2011). This includes the introduction of a new product/service, production technology, and organizational management method (OECD, 2005, 2010). Although the induction of innovation may be either new to the world, new to the market or new to firms, it all shows the importance for the survival/existence and development of firms through the retention and widening of the customer base, opening of new markets, reduction of production costs, and allowing more efficient management (Agarwal et al., 2003; Hausman and Johnston, 2014). Consequently, innovation attracts lots of efforts from scholars to examine its nature, determinants and driving forces which again provides insights for managers/owners and governmental agencies into the promotion of innovation in firms (Acs and Audretsch, 1988; Freeman, 1982; Hall and Rosenberg, 2010).

Extant research on innovation literature has investigated a range of different determinants of innovation arising from both external and internal factors. The external factors include components outside firms that have an influence on the innovation activities such as the dynamic business environment, technological development trends, preference changes of customers and suppliers and also the industrial and economic structure (Capaldo et al., 2003; De Jong and Vermeulen, 2004; Romijn and Albaladejo, 2002). Meanwhile, the internal factors comprise of the resource availability, the capability to sense, seize and transform business opportunities into real 
innovation output, and the characteristics of managers/owners such as risk-taking (Mel et al., 2009). Furthermore, recent scholars argue that not one single factor influences the innovation output, but the combination of both internal and external factors benefits innovation of firms, of which the internal ones play a crucial role in those innovative activities (Hogan et al., 2011; Ngo and O'Cass, 2009). Among those factors, slack resources are a key ingredient that promote firms' innovation.

\subsection{Slack resources}

Slack resources are well explored in their role for firm performance. Slack resources are defined as the overabundance of resources that exceed the required amount to ensure the normal production of firms (Bourgeois, 1981; Geiger and Cashen, 2002; Nohria and Gulati, 1997). It is the unused resources that exist within firms and can be mobilized to serve particular needs of firms (Child, 1972; Cohen et al.,1972). Slack resources are also considered as the non-fully utilized resources that firms can further fully utilize through appropriate strategies and actions. The existence of slack resources is obviously due to the nature of indivisibility of resources (Penrose, 1959). Because 'resources are only obtainable in discrete amounts', thus, if a resource is demanded for a single activity or service, it would not be fully utilized for the need of that demand (Penrose, 1995, p67). Consequently, this non-fully deployed resource creates an excess of resource within the firm. In addition, the knowledge created through business operations further generates the resource excess through more efficient resource deployment methods (Cyert and March, 1963). In other words, the knowledge creation allows firms to reduce the execution time required for normal activities, thus generating slack (Pitelis, 2007).

The importance of slack resources in innovation is well understood. Prior research has shown that slack is considered as the determinant and also driving force for firms to innovate (Cyert et al., 1959; Damanpour, 1991). The presence of slack provides a buffer against shortage of resources for innovation activities which is common among SMEs (Mishina et al., 2004). Slack resources also motivate firms to search for business opportunities to deploy that slack, resulting in a new product a business process. The presence of slack encourages owners/managers to invest in innovative business activities that may lead to the introduction of a new product (Penrose, 1959). In addition, the excess resource not only provides an endogenous incentive to innovate but also enables firms to recombine available resources in more creative ways (Nason and Wiklund, 2015). However, notwithstanding the extensive theoretical and empirical studies, the relationship between resource slack and innovation remains ambiguous. Some scholars argue that too much slack creates struggles for firms in mobilizing resources for innovation activities as the necessary resource is locked within such slack (Fama, 1980; Katila and Shane, 2005). As a result, this prevents firms from investing resources in innovative activities. Furthermore, the high level of slack indicates the lower risk-taking levels of the owner/managers, thus, does not encourage them to look for business opportunities to fully deploy that slack (Singh, 1986).

A first possible explanation for the controversial results is that the impact depends on the slack types and firms' characteristics. First, slack differs among firms. For example, in small firms, slack rarity is worse than in larger counterparts. Slack is also found to have different impact mechanisms in privately held firms than in public firms (George, 2005). Second, slack resources are different in terms of availability, fungibility, absorbability, and recoverability (Voss et al., 2008). For example, there is absorbed and unabsorbed slack, genetic and rare slack. These differences influence the role of slack in supporting innovation. For instance, there is slack that is more fixed in certain business activities, therefore, is not easily allocated to other tasks. This slack is supposed to have less impacts on innovation. Among those types, financial and human resource slack are typical in organizations (Voss et al., 2008). These forms of slack are also important for SMEs to overcome 
the common financial and human capital constraints in their survival and development as will be explained next.

Financial slack typically refers to the excessive financial resources for the normal operation of an organization (Ang and Straub, 1998; Voss et al., 2008). These financial resources are also not currently allocated for certain business activities (Bizzi, 2017; Yanadori and Cui, 2013). Extant research has proven the positive influence of financial slack on innovation of firms. For instance, Natividad (2013) argued that the presence of a high level of financial slack provides a resource buffer for innovation activities, thus, enables firms to innovate. However, in small-scaled familyrun businesses, the impact directions may differ. According to the stewardship theorists, in family business, the owners/managers have the responsibility to look after dependants (Davis et al., 1997). They act not only on behalf of the business but also of their family. Consequently, they first have to ensure the benefits of the whole family (Corbetta and Salvato, 2004; Donaldson and Davis, 1991). In other words, the well-being of family is strongly connected with the successful performance of the family's business. Therefore, if the unused financial resources are used to develop innovation, it may lead to constraints in the family's living standard due to the risky nature of innovation activities. Instead, the owners/managers prefer to use this financial slack in less risky activities.

Moreover, in these small-scaled family businesses, there is a blurred line between firm and family operational activities, especially in less developed countries. The underemployed financial resource can be used to meet the demand of family rather than firm activities. In addition to that, financial slack is completely divisible across multiple activities (Greve, 2003). Thus, any available financial slack will be deployed for currently demanded activities, that are typically constrained by limited internal resources in small firms, rather than be invested in innovation that requires long-term commitment (Parida and Örtqvist, 2015). Consequently, possessing a high level of financial slack reduces the likelihood of introducing a new product or business process. Therefore, it is theorized that:

\section{Hypothesis 1 (H1): Financial slack negatively influences the probability of having innovation}

Human resource slack is defined as the human resources in excess of that required for the efficient operation of an organization (Williamson, 1963). The presence of this excessive staff enables firms to allocate the required human resources to additional tasks without interfering daily operational activities (Welbourne et al.,1999). From the stewardship theory perspective, because the firm and family interests are guaranteed, the owners are more open to invest this human resource slack to prepare for future growth. Moreover, human resource slack is less flexible than financial slack. It is also an absorbed slack which is not easily redeployed into variety use (Mishina et al., 2004). Therefore, it is not easy for the owner to use that unused resource to meet the resource demands of family activities. Instead, the human resource slack is preferred to be exploited within firms.

The presence of high levels of human resource slack means that the productivity of the workforce is not currently maximized. In other words, the workforce does not work at maximum capacity. This encourages the owner to further deploy the underemployed staff by allocating this excessive human resource to additional tasks. The reallocation of human resources allows firms to effectively respond to emerging business opportunities and achieve higher growth. In other words, human resource slack stimulates firms to search and transfer business opportunities, resulting in the introduction of a new product or a new market (Chang et al.,2012). Additionally, excess human resources also motivate firms to reconfigure the current production technology to maximize the capacity of the current workforce. For instance, introducing a new business process is also a way to improve the productivity in terms of human resource utilization. Therefore, we posit that: 


\subsection{The moderation role of institutional context}

For SMEs that are typically facing resource constraints, the availability of slack resources is essential to engage in innovation activities and offer new products or business processes. However, slack resources do not act in isolation. Though slack equips firms with additional resources or motivates them to find business opportunities, the innovation outcome results from a range of connected activities. Thus, firms still require other factors in addition to slack. Among those factors, the institutional context plays an important role in enhancing the impact of slack resources on innovation as will be explained next.

Institutions are 'social structures that have attained a high degree of resilience' (Scott, 1995: 33). They include different cognitive, normative and regulative elements that operate at different levels of jurisdiction in the interpersonal, organizational, national, and global system. Institutions contribute to the formation of a business environment for firms, thus having influence on the operation and development of businesses (North, 1991). The importance of institutions in firm's performance can be illustrated through the facilitating or hindering role. For instance, institutions can help alter the constraints and the structure of incentives in a society to direct self-interested behaviour towards either more or less economically productive activities (Baumol 1990; Nee, 1996). Institutions also have an impact on the innovation of firms in both direct and indirect ways (Wang, 2013). The direct effect is reducing uncertainty in the business environment through a stable legislation framework (World Bank, 2014). Meanwhile, creating favourable conditions for firms to innovate such as developed inputs and outputs market is an example of the indirect impact of institutions on innovation (Mokyr, 2007).

As noted, high levels of financial slack hinder the effort of introducing innovation in the firm. Though the excessiveness of financial resources provides a financial buffer for firms, the stewardship role does not encourage owners to invest the excess resources in new activities. The fungibility of that type of slack instead allows owners to easily allocate the financial excessiveness to activities that ensure the welfare of family rather than innovation activities. However, operating in different institutional levels may lead to different results in the impact of financial slack on innovation. For instance, in a region with a stable legal framework, the business environment is less uncertain, thus, reducing the perceived risk of owners and transaction costs when implementing innovation activities (Williamson, 2005). Consequently, they are more open to invest the financial slack in developing new products or acquiring a new production technology. More importantly, the development of institutions may remove the owners' burden of ensuring family benefits. In a region with a developed financial market, the access to financial resources is more favourable, allowing the owners to have more alternative choices to ensure family welfare rather than using the firm's financial slack (Brown et al., 2013; Hsu et al., 2014). Additionally, firms have more access to other necessary resources to combine with financial slack in developing a new product or improve current products. Taken together, high levels of institutional development may help to exit the family wellbeing trap, thus liberating the unused financial resources. Therefore, it is hypothesized that:

\section{Hypothesis 3 (H3): The negative impact of financial slack is lessened in firms located in areas with a more favourable business environment}

Human resource slack improves innovation. The excess of this slack type encourages owners to first search for business opportunities and second reconfigure business operations to fully deploy the underemployed staff. First, high levels of institutional development allow firms to have favourable conditions in accessing financial and other resources such as premises, information and 
technology to supplement for human resource slack. Firms also have more advantages to develop their capabilities in a stable policy condition. These are crucial for the successful development of a new product because innovation requires the combination of a range of resources and capabilities (Hogan et al., 2011). Second, the development of institutions contributes to the removal of barriers to market entrance and creates an equal playing field among businesses. Firms have less constraints when entering/opening new markets with new products or expanding the current market with improved products as a result of consuming human resource slack. Consequently, this enriches the impact of human resource slack on innovation. Therefore, it is hypothesized that:

Hypothesis 4 (H4): The positive impact of human resource slack is stronger in firms located in areas with a more favourable business environment

\section{Methodology}

\subsection{Sample}

This study explores the longitudinal Vietnamese SME dataset collected biennially from 2005 to 2015. The surveys were conducted under the collaboration of Central Institute for Economic Management (Viet Nam), Institute for Labour and Social Affairs (Viet Nam), and University of Copenhagen with sponsoring by the Danish Development Agency and UNU-WIDER. The surveys cover around 2,500 small and medium manufacturing firms in 10 provinces of Viet Nam namely Hanoi, Ha Tay (ex), Hai Phong, Phu Tho, Nghe An, Quang Nam, Lam Dong, Khanh Hoa, Ho Chi Minh city and Long An (CIEM, 2007). The sample selection is implemented with the aim to ensure the correct representation of the manufacturing sector development in Viet Nam.

\subsection{Measurements}

\subsubsection{Dependent variables}

In the study, we investigated three binary innovation dependent variables, namely radical, incremental product and process innovation. In the survey, firms were asked whether they introduced the following types of innovation: a new product, a major improvement to a current product or a new technology/production process (OECD, 2005). The radical product innovation is determined by whether firm introduced a new product to the market. Some authors argued that the radical product innovation relates to the introduction of a product that is totally new to the market. However, in our sample, the radical product innovation is only new to firms but demonstrates a huge effort from these small firms to introduce this new product (Slater et al., 2014). Thus, our sample could be a reasonable proxy for radical product innovation. The second dependent variable is incremental product innovation which is defined by the introduction of a major improvement to current products. Meanwhile, process innovation is determined by the application of a new product process or technology. These three dependent variables were coded as binary variables that assigned value 1 if introducing innovation and 0 otherwise.

\subsubsection{Explanatory variables}

We measured financial slack as the difference between the ratio of total sale to total assets of firms and the mean ratio for all firms operating in the same two-digit industry (Bourgeois, 1981). Meanwhile, human resource slack was calculated by subtracting the number of full-time equivalent employees from the total sales of firms and the mean ratio of the industry (Vanacker et al., 2017). 
These two measures present the physical and human capital excess that firms use to generate specific amount of sales as compared with other counterparts.

For institutional context, the Provincial Competitiveness Index (PCI) is employed to represent the level of business favourability. The PCI was first introduced in 2005 in Viet Nam and conducted annually (Malesky, 2017). The overall PCI comprises ten sub-indices, reflecting economic governance areas that affect private sector development. A province that is considered to perform well on the PCI is the one that has: (i) low entry costs for business start-up; (ii) easy access to land and security of business premises; (iii) a transparent business environment and equitable business information; (iv) minimal informal charges; (v) limited time requirements for bureaucratic procedures and inspections; (vi) limited crowding out of private activity from policy biases toward state, foreign, or connected firms; (vii) proactive and creative provincial leadership in solving problems for enterprises; (viii) developed and high-quality business support services; (ix) sound labour training policies; and (x) fair and effective legal procedures for dispute resolution. The PCI is the weighted mean of the ten sub-indices with a maximum score of 100 points.

\subsubsection{Control variables}

Four control variables that are important for firm-level analyses-namely firm size, firm age, industry, and legal form-were included. Firm size was measured by the number of the total regular workforce $(\mathrm{log})$. Firm age was measured by the number of years a firm was in business (log). Firm industries were classified based on the Vietnamese Standard Industrial Classification that complies with the International Standard Industrial Classification (OECD, 2009). Legal form was classified as household and non-household firms (Romijn and Albaladejo, 2002). The variables are summarized in Table 1.

Table 1: Independent variables in the innovation models

\begin{tabular}{|c|c|}
\hline Variables & Explanation of variables \\
\hline Financial slack & $\begin{array}{l}\text { Financial slack calculated by comparison between the firm's ratio of total sale over } \\
\text { total assets and the mean ratio of firms in the same industry (2-digit industrial code) }\end{array}$ \\
\hline Human resource slack & $\begin{array}{l}\text { Human resource slack calculated by comparison between the firm's ratio of total } \\
\text { employees over total sale and the mean ratio of firms in the same industry (2-digit } \\
\text { industrial code) }\end{array}$ \\
\hline $\mathrm{PCl}$ & $\begin{array}{l}\text { Provincial Competitiveness Index calculated by taking weighted mean of ten sub- } \\
\text { indices with a maximum score of } 100 \text { points }\end{array}$ \\
\hline Firm Size & The total number of full-time employees (Log) \\
\hline Firm Age & Number of years in business (Log). \\
\hline Household & Dummy variable. If firms are household, Legal form $=1$, otherwise Legal form $=0$ \\
\hline Low industry & $\begin{array}{l}\text { Dummy variable. If firms's industry is low technology, thus, Low_industry }=1 \text {, } \\
\text { otherwise, Low industry }=0\end{array}$ \\
\hline $\begin{array}{l}\text { Medium low industry } \\
\text { (Ind MedLow) }\end{array}$ & $\begin{array}{l}\text { Dummy variable. If firms' industry is medium low technology, thus, } \\
\text { Medium Low industry }=1 \text {, otherwise, Medium Low industry=0 }\end{array}$ \\
\hline Medium high industry & Dummy variable. If firms' industry is medium high technology, thus, \\
\hline (Ind_MedHigh) & Medium_High_industry=1, otherwise, Medium_High_industry $=0$ \\
\hline High industry (Ind_High) & $\begin{array}{l}\text { Dummy variable. If firms' industry is high technology, thus, High_industry=1, } \\
\text { otherwise, High_industry }=0\end{array}$ \\
\hline
\end{tabular}

Source: Authors' calculation based on the 2005-15 Vietnamese SMEs data.

\subsection{Bias testing}

We conducted a number of tests and techniques to ensure the avoidance of bias in the estimation. First, the survey followed a random sampling procedure to assure the representation of different types of firms in our sample, thus, sample selection bias does not appear to be a problem (Pannucci and Wilkins, 2010). Second, the high response rate of typical governmental surveys indicates that 
non-response bias is not an issue (Armstrong and Overton, 1977). Third, we also performed a Harman's single factor test to find out whether there is a presence of common method bias. The results show that the first factor did not account more than fifty per cent of variance of other factors, therefore, common method bias seems not to be a main issue on our estimation (Podsakoff et al., 2003). Finally, together with the inclusion of PCI data from the Viet Nam Chamber of Commerce and Industry, the application of direct interviews with firm's owner/managers who have outstanding knowledge about the operation of firms helps us to limit the bias arising from using a single data source.

\subsection{Research method}

As the dependent variables are binary, we apply binary probit regression as a method to test our hypotheses (Wooldridge, 2010). The specific model is described as:

$$
E(y \mid x)=\exp (x \beta) /[1+\exp (x \beta)]
$$

where $\mathrm{E}(\mathrm{y} \mid \mathrm{x})$ is a binary probit function and $\mathrm{x}$ is a set of explanatory and control variables.

A firm would initially be better endowed with innovation, thus raising concerns about endogeneity leading to estimation bias. Therefore, statistical techniques such as adding control variables and/or using robust standard errors will be applied to control for endogeneity problem.

\section{Results and discussion}

\subsection{Results}

Table 2 presents the descriptive statistics and correlation matrix on the variables used in the study. There was 65 per cent of our sample operating as household firms, indicating a high proportion of informal firms in the Vietnamese manufacturing industry. In our sample, as we keep track firms during a 10-year period since 2005, firms were quite mature with the average age of more than 14 years in business which is typical in manufacturing industries. The average size of firms was 14 regular full-time employees. The majority of firms operated in low and medium low technology industries such as food and beverage, garment and textiles. Only nine per cent of firms are in medium high technology industries while two per cent in high tech. This is the case of Vietnamese manufacturing industries which is confirmed in the industrialization policy during the last 20 years (Anh et al., 2016).

The results also show the proportion of firms that introduced radical, incremental product and process innovation. While 32 per cent of firms had major improvements to current products, there was only 13.8 per cent launching a new production process. The percentage of firms offering new products to the market was 12.8 per cent. Table 2 also illustrates significant correlations between the financial and human resource slack, firm size, firm age, legal form, and business environment favourability. 
Table 2: Descriptive statistics and correlation matrix

\begin{tabular}{|c|c|c|c|c|c|c|c|c|c|c|c|c|c|c|}
\hline & & Mean & SD & 1 & 2 & 3 & 4 & 5 & 6 & 7 & 8 & 9 & 10 & 11 \\
\hline 1 & Radical product innovation & 0.128 & 0.334 & & & & & & & & & & & \\
\hline 2 & $\begin{array}{l}\text { Incremental product } \\
\text { innovation }\end{array}$ & 0.324 & 0.468 & $0.256^{* * *}$ & & & & & & & & & & \\
\hline 3 & Process innovation & 0.130 & 0.336 & $0.254 * * *$ & $0.372 * * *$ & & & & & & & & & \\
\hline 4 & Financial slack & 0.656 & 3.184 & -0.004 & $-0.025 * *$ & -0.013 & & & & & & & & \\
\hline 5 & Human resource slack & 0.001 & 0.009 & $0.026^{* *}$ & 0.014 & $0.026 * *$ & -0.003 & & & & & & & \\
\hline 6 & PCI & 56.224 & 5.040 & $0.101^{* * *}$ & $\begin{array}{c}- \\
0.108^{* * *}\end{array}$ & $\begin{array}{c}- \\
0.056^{* * *}\end{array}$ & -0.002 & $\begin{array}{c}- \\
0.194^{* * *}\end{array}$ & & & & & & \\
\hline 7 & Firm size & 14.106 & 27.462 & $0.083^{* * *}$ & $0.155^{* * *}$ & $0.197 * * *$ & $0.056^{* * *}$ & $0.027 * *$ & $0.031^{* *}$ & & & & & \\
\hline 8 & Firm age & 14.242 & 9.522 & $-0.032 * *$ & $\begin{array}{c}- \\
0.099 * * *\end{array}$ & $\begin{array}{c}- \\
0.078 * * *\end{array}$ & $\begin{array}{c}- \\
0.056^{* * *}\end{array}$ & 0.001 & $-0.019 *$ & $\overline{-}^{-}$ & & & & \\
\hline 9 & Legal form & 0.654 & 0.476 & $\begin{array}{c}- \\
0.066^{* * *}\end{array}$ & $\begin{array}{c}- \\
0.138^{* * *}\end{array}$ & $\begin{array}{c}- \\
0.164^{* * *}\end{array}$ & -0.004 & -0.013 & $\begin{array}{c}- \\
0.097^{* * *}\end{array}$ & $\stackrel{-}{0.449 * * *}$ & $0.187 * * *$ & & & \\
\hline 10 & $\begin{array}{l}\text { Medium low technology } \\
\text { industry }\end{array}$ & 0.241 & 0.427 & $0.025 * *$ & $0.048 * * *$ & $-0.016 *$ & $0.019 *$ & -0.006 & 0.015 & $\begin{array}{c}- \\
0.033^{* * *}\end{array}$ & $-0.024 * *$ & 0.002 & & \\
\hline 11 & $\begin{array}{l}\text { Medium high technology } \\
\text { industry }\end{array}$ & 0.087 & 0.282 & $0.036^{* * *}$ & $0.084 * * *$ & -0.006 & -0.013 & -0.003 & $\begin{array}{c}- \\
0.037^{* * *}\end{array}$ & $-0.023^{* *}$ & $-0.018^{*}$ & $0.032 * * *$ & $0.174^{* * *}$ & \\
\hline 12 & High technology industry & 0.022 & 0.148 & $0.086 * * *$ & $0.053 * * *$ & $0.062 * * *$ & -0.012 & -0.001 & 0.013 & $0.041^{* * *}$ & $-0.025 * *$ & $\begin{array}{c}- \\
0.056^{* * *}\end{array}$ & $\begin{array}{c}- \\
0.085^{* * *}\end{array}$ & $\begin{array}{c}- \\
0.047 * * *\end{array}$ \\
\hline
\end{tabular}

Note: Spearman correlation. ${ }^{*} p<0.05 ;{ }^{* *} p<0.01$; and ${ }^{* \star *} p<0.001$

Source: Authors' calculation based on the 2005-2015 Vietnamese SMEs data. 
Table 3 exhibits the results of our estimation on the impact of financial slack on the three mentioned innovation types. The results show that the financial slack is statistically significantly negatively related to incremental product $(\mathrm{p}<0.001)$ and process innovation $(\mathrm{p}<0.05)$ (see Model 4 and 6$)$. In other words, firms encountering financial slack are less likely to make improvement to the current product, and to engage in a new technology/production process. However, the results do not demonstrate a statistically significant impact of financial slack on the introduction of a new product (Model 1). Therefore, H1 was partly confirmed.

Table 3: The impact of financial slack on innovation

\begin{tabular}{|c|c|c|c|c|c|c|}
\hline & \multicolumn{2}{|c|}{ Radical product innovation } & \multicolumn{2}{|c|}{$\begin{array}{l}\text { Incremental product } \\
\text { innovation }\end{array}$} & \multicolumn{2}{|c|}{ Process innovation } \\
\hline & Model 1 & Model 2 & Model 3 & Model 4 & Model 5 & Model 6 \\
\hline \multicolumn{7}{|l|}{ Explanatory variable } \\
\hline Financial slack & & -0.004 & & $-0.021^{\star \star \star}$ & & $-0.014^{*}$ \\
\hline \multicolumn{7}{|l|}{ Control variables } \\
\hline Firm size (log) & $0.118^{\star \star \star}$ & $0.119 * \star \star$ & $0.261^{\star \star \star}$ & $0.264^{\star \star \star}$ & $0.282^{\star \star \star}$ & $0.284^{\star \star \star}$ \\
\hline Firm age (log) & $0.057^{\star *}$ & $0.056^{\star \star}$ & 0.019 & 0.013 & -0.011 & -0.015 \\
\hline $\begin{array}{l}\text { Medium low technology } \\
\text { industry }\end{array}$ & $0.204^{\star \star \star}$ & $0.204^{\star \star *}$ & $0.230 * \star *$ & $0.233^{\star \star *}$ & -0.057 & -0.056 \\
\hline $\begin{array}{l}\text { Medium high technology } \\
\text { industry }\end{array}$ & $0.301 * \star \star$ & $0.301 * \star \star$ & $0.477^{\star \star \star}$ & $0.476^{\star \star \star}$ & -0.065 & -0.068 \\
\hline High technology industry & $0.290 * \star \star$ & 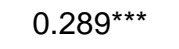 & 0.127 & 0.120 & 0.091 & 0.086 \\
\hline Legal form & $-0.184^{\star \star \star}$ & $-0.173^{\star \star *}$ & $-0.095^{\star \star}$ & $-0.090^{\star *}$ & $-0.147^{\star \star \star *}$ & $-0.144^{\star \star \star}$ \\
\hline Year 2007 & $-1.395^{\star \star \star}$ & $-1.395^{\star \star \star}$ & $-0.396^{\star \star \star}$ & $-0.396^{\star \star \star}$ & $-0.488^{\star \star \star}$ & $-0.487^{\star \star \star}$ \\
\hline Year 2009 & $-1.672^{\star \star \star}$ & $-1.673^{\star \star \star}$ & $-0.463^{\star \star \star}$ & $-0.463^{\star \star \star}$ & $-0.548^{\star \star \star}$ & $-0.548^{\star \star \star}$ \\
\hline Year 2011 & $-2.259^{\star \star \star}$ & $-2.259^{\star \star \star}$ & $-1.192^{\star \star \star}$ & 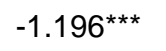 & $-0.951^{* \star *}$ & $-0.951^{\star \star \star}$ \\
\hline Year 2013 & $-2.274^{\star \star \star}$ & $-2.227^{\star \star \star}$ & $-1.202^{\star \star \star}$ & $-1.204^{\star \star \star}$ & $-0.943^{\star \star *}$ & $-0.942^{\star \star \star}$ \\
\hline Year 2015 & $-0.425^{\star \star \star}$ & $-0.425^{\star \star \star}$ & $-1.336^{\star \star \star}$ & $-1.338^{\star \star \star}$ & $-1.106^{\star \star \star}$ & $-1.105^{\star \star \star}$ \\
\hline Constant & $-0.603^{\star \star \star}$ & $-0.600^{\star \star *}$ & $-0.366^{\star \star \star}$ & $-0.341^{\star \star \star}$ & $-1.014^{\star \star \star}$ & $-1.002^{\star \star \star}$ \\
\hline Observations & 15,589 & 15,589 & 15,589 & 15,589 & 15,589 & 15,589 \\
\hline$\chi^{2}$ & $2240.924^{\star \star \star}$ & $2240.40^{\star \star \star}$ & $2717.92^{\star \star \star}$ & $2770.08^{\star \star}$ & $1412.91^{\star \star \star}$ & $1414.77^{\star \star *}$ \\
\hline Pseudo R2 & 0.2808 & 0.2808 & 0.1638 & 0.1653 & 0.1462 & 0.1470 \\
\hline
\end{tabular}

Note: Probit regression. Based: Low technology industry, year 2005. ${ }^{*} p<0.05$; ${ }^{\star *} p<0.01$; and ${ }^{\star * \star} p<0.001$

Source: Authors' calculation based on the 2005-15 Vietnamese SMEs data.

Table 4 demonstrates the estimation results of the impact of human resource slack on the three mentioned innovation types. The estimation results show that human resource slack has a positive impact on all three mentioned innovation types at any considered statistical significance levels (Models 8, 10 and 12). In other words, firms encountering human resource slack are more likely to introduce new products, to make improvement to the current product, and engage in a new technology/production process. Therefore, $\mathrm{H} 2$ was confirmed. 
Table 4: The impact of human resource slack on innovation

\begin{tabular}{|c|c|c|c|c|c|c|}
\hline & \multicolumn{2}{|c|}{ Radical product innovation } & \multicolumn{2}{|c|}{$\begin{array}{c}\text { Incremental product } \\
\text { innovation }\end{array}$} & \multicolumn{2}{|c|}{ Process innovation } \\
\hline & Model 7 & Model 8 & Model 9 & Model 10 & Model 11 & Model 12 \\
\hline \multicolumn{7}{|l|}{ Explanatory variable } \\
\hline Human resource slack & & $7.925^{\star \star \star}$ & & $4.522^{\star \star}$ & & $7.622^{\star \star \star}$ \\
\hline \multicolumn{7}{|l|}{ Control variables } \\
\hline Firm size (log) & $0.118^{\star \star \star}$ & $0.118^{\star \star \star}$ & $0.261^{\star \star \star}$ & $0.261^{\star \star \star}$ & $0.282^{\star \star \star}$ & $0.282^{\star \star \star}$ \\
\hline Firm age (log) & $0.057^{\star \star}$ & $0.056^{*}$ & 0.019 & 0.019 & -0.011 & -0.011 \\
\hline $\begin{array}{l}\text { Medium low technology } \\
\text { industry }\end{array}$ & $0.204^{\star \star \star}$ & $0.204^{\star \star *}$ & $0.230^{\star \star \star}$ & 0.231 *** & -0.057 & -0.056 \\
\hline $\begin{array}{l}\text { Medium high technology } \\
\text { industry }\end{array}$ & $0.301^{\star \star \star}$ & $0.302^{\star \star \star}$ & $0.477^{\star \star *}$ & $0.477^{\star \star \star}$ & -0.065 & -0.065 \\
\hline High technology industry & 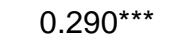 & $0.291^{\star \star \star}$ & 0.127 & 0.127 & 0.091 & 0.092 \\
\hline Legal form & $-0.184^{\star \star \star}$ & $-0.174^{\star \star \star}$ & $-0.095^{\star \star}$ & $-0.095^{\star \star}$ & $-0.147^{\star \star \star}$ & $-0.147^{\star \star \star}$ \\
\hline Year 2007 & $-1.395^{\star \star \star}$ & $-1.393^{\star \star \star}$ & $-0.396^{\star \star \star}$ & $-0.395^{\star \star \star}$ & $-0.488^{\star * \star}$ & $-0.487^{\star \star \star}$ \\
\hline Year 2009 & $-1.672^{\star \star \star}$ & $-1.671^{\star \star \star}$ & $-0.463^{\star \star \star}$ & $-0.462^{\star \star \star}$ & $-0.548 * \star \star$ & $-0.547^{\star \star \star}$ \\
\hline Year 2011 & 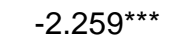 & $-2.258^{\star \star \star}$ & $-1.192^{\star \star \star}$ & $-1.193^{\star \star \star}$ & $-0.951^{\star \star \star}$ & $-0.95^{\star \star \star}$ \\
\hline Year 2013 & $-2.274^{\star \star \star}$ & $-2.273^{\star \star \star}$ & $-1.202^{\star \star \star}$ & $-1.202^{\star \star \star}$ & $-0.943^{\star \star \star}$ & $-0.942^{\star \star \star}$ \\
\hline Year 2015 & $-0.425^{\star \star \star}$ & $-0.424^{\star \star \star}$ & $-1.336^{\star \star \star}$ & $-1.336^{\star \star \star}$ & $-1.106^{\star \star \star}$ & $-1.104^{\star \star \star}$ \\
\hline Constant & $-0.603^{\star \star \star}$ & $-0.603^{\star \star \star}$ & $-0.366^{\star \star \star}$ & $-0.362^{\star \star \star}$ & $-1.014^{\star \star \star}$ & $-1.014^{\star \star \star}$ \\
\hline Observations & 15,589 & 15,589 & 15,589 & 15,589 & 15,589 & 15,589 \\
\hline$\chi^{2}$ & $2240.924^{\star \star *}$ & $2293.92^{\star \star \star}$ & $2717.92^{\star \star \star}$ & $2735.05^{\star \star \star}$ & $1412.91^{\star \star \star}$ & $1458.49^{\star \star \star}$ \\
\hline Pseudo R2 & 0.2808 & 0.2810 & 0.1638 & 0.1639 & 0.1462 & 0.1464 \\
\hline
\end{tabular}

Note: Probit regression. Based: Low technology industry, year 2005. ${ }^{\star} p<0.05$; ${ }^{\star \star} p<0.01$; and ${ }^{\star \star \star} p<0.001$

Source: Authors' calculation based on the 2005-15 Vietnamese SMEs data.

The estimation for the moderation impact of institutional context on the relationship between financial slack and human resource slack and innovation is illustrated in Tables 5 and 6 . As expected, a location in regions with higher levels of institutions reduces the negative impact of financial slack on incremental product and process innovation (Models 14 and 15). However, this location does not statistically impact on the relationship between financial slack and radical product innovation (Model 13). Therefore, H3 was partially confirmed. The results in Models 17 and 18 present the negative moderation of institutional context on the relationship between human resource slack and incremental product and process innovation. In other words, firms located in a more favourable business environment will gain less positive impact from human resource slack. Therefore, $\mathrm{H} 4$ was rejected. 
Table 5: The moderation impact of institutional context on the relationship between financial slack and innovation

\begin{tabular}{|c|c|c|c|}
\hline & $\begin{array}{c}\text { Radical product } \\
\text { innovation }\end{array}$ & $\begin{array}{c}\text { Incremental product } \\
\text { innovation }\end{array}$ & $\begin{array}{c}\text { Process } \\
\text { innovation }\end{array}$ \\
\hline & Model 13 & Model 14 & Model 15 \\
\hline \multicolumn{4}{|l|}{ Explanatory variable } \\
\hline Financial slack & 0.043 & $-0.177^{\star \star}$ & $-0.206^{\star}$ \\
\hline $\mathrm{PCl}$ & $-0.010^{*}$ & $-0.006^{*}$ & $-0.007^{*}$ \\
\hline Financial slack * $\mathrm{PCl}$ & -0.001 & $0.003^{*}$ & $0.003^{*}$ \\
\hline \multicolumn{4}{|l|}{ Control variables } \\
\hline Firm size (log) & $0.054^{*}$ & $0.267^{\star \star \star}$ & $0.280 * \star \star$ \\
\hline Firm age (log) & $0.135^{\star \star \star}$ & -0.008 & -0.017 \\
\hline Medium low technology industry & $0.151^{\star *}$ & $0.215^{\star \star \star}$ & $-0.087^{\star}$ \\
\hline Medium high technology industry & 0.126 & $0.387^{\star \star \star}$ & -0.115 \\
\hline High technology industry & 0.154 & -0.016 & 0.049 \\
\hline Legal form & $-0.169 * \star$ & -0.057 & -0.085 \\
\hline Year 2009 & $-0.267^{\star \star \star}$ & -0.058 & -0.048 \\
\hline Year 2011 & $-0.835^{\star \star \star}$ & $-0.777^{\star \star \star}$ & $-0.437^{\star \star \star}$ \\
\hline Year 2013 & $-0.862^{\star \star \star}$ & $-0.782^{\star \star \star}$ & $-0.429 * * *$ \\
\hline Year 2015 & $0.981^{\star \star \star}$ & $-0.9 * \star \star$ & $-0.568^{\star \star \star}$ \\
\hline Constant & $-1.482^{\star \star \star}$ & $-0.385^{\star}$ & $-1.099 * \star \star$ \\
\hline Observations & 12,787 & 12,787 & 12,787 \\
\hline$\chi^{2}$ & $1165.27^{\star \star \star *}$ & $1701.53^{\star \star \star}$ & 690.09 \\
\hline Pseudo R2 & 0.2213 & 0.1300 & 0.1038 \\
\hline
\end{tabular}

Note: Probit regression. Based: Low technology industry, year 2005. ${ }^{\star} p<0.05$; ${ }^{\star \star} p<0.01$; and ${ }^{\star * \star} p<0.001$

Source: Authors' calculation based on the 2005-15 Vietnamese SMEs data. 
Table 6: The moderation impact of institutional context on the relationship between financial slack and innovation

\begin{tabular}{|c|c|c|c|}
\hline & $\begin{array}{c}\text { Radical product } \\
\text { innovation }\end{array}$ & $\begin{array}{c}\text { Incremental product } \\
\text { innovation }\end{array}$ & $\begin{array}{l}\text { Process } \\
\text { innovation }\end{array}$ \\
\hline & Model 16 & Model 17 & Model 18 \\
\hline \multicolumn{4}{|l|}{ Explanatory variable } \\
\hline Human resource slack & -70.981 & $30475.89 * \star \star$ & $35621^{\star \star \star}$ \\
\hline $\mathrm{PCl}$ & $-0.011^{*}$ & -0.002 & -0.003 \\
\hline Human resource slack * $\mathrm{PCl}$ & -31.853 & $-785.135^{\star \star \star}$ & $-870.813^{\star \star \star}$ \\
\hline \multicolumn{4}{|l|}{ Control variables } \\
\hline Firm size (log) & $0.051^{*}$ & $0.258^{* \star *}$ & $0.276^{\star \star \star}$ \\
\hline Firm age (log) & $0.138^{\star \star \star}$ & 0.007 & -0.007 \\
\hline Medium low technology industry & $0.147^{\star \star}$ & $0.201^{\star \star \star}$ & $-0.092^{*}$ \\
\hline Medium high technology industry & 0.120 & $0.366^{\star \star *}$ & $-0.129 *$ \\
\hline High technology industry & 0.150 & -0.038 & 0.029 \\
\hline Legal form & $-0.162^{\star *}$ & -0.016 & -0.046 \\
\hline Year 2009 & $-0.274^{\star \star \star}$ & $-0.101^{\star \star}$ & -0.073 \\
\hline Year 2011 & $-0.847^{\star \star \star}$ & $-0.852^{\star \star \star}$ & $-0.491^{\star \star \star}$ \\
\hline Year 2013 & $-0.875^{\star \star \star}$ & $-0.858^{\star \star \star}$ & $-0.483^{\star \star \star}$ \\
\hline Year 2015 & $0.970 * \star \star$ & $-0.978^{\star \star *}$ & $-0.624^{* \star *}$ \\
\hline Constant & $-1.428^{\star \star \star}$ & $-0.519 * \star$ & $-1.295^{\star \star \star}$ \\
\hline Observations & 12,787 & 12,787 & 12,787 \\
\hline$\chi^{2}$ & $1171.94^{\star \star *}$ & $1713.03^{\star \star \star}$ & $719.15^{\star \star \star}$ \\
\hline Pseudo R2 & 0.2214 & 0.1367 & 0.1088 \\
\hline
\end{tabular}

Note: Probit regression. Based: Low technology industry, year 2005. ${ }^{\star} p<0.05$; ${ }^{\star \star} p<0.01$; and ${ }^{\star * \star} p<0.001$

Source: Authors' calculation based on the 2005-15 Vietnamese SMEs data.

\subsection{Discussion}

Around more than 80 per cent of Vietnamese SMEs experienced some constraints (CIEM et al. 2016), including financial shortage, limited demand, and fierce competition. Therefore, taking use of slack resources should be one of the important solutions for dealing with their main constraints. The data analysis revealed the impact of both financial and human resource slack on innovation but in reverse directions. Financial slack shows the negative impact on innovation in terms of incremental product and process innovation, meaning that firms encountering financial slack are less likely to make improvement to the current product, and to engage in a new technology/production process. This confirms the firm owners' stewardship role in managing the family welfare (Donaldson and Davis, 1991). The flexibility of financial slack allows firm owners to direct the use of those excessive resources to meet the family demands rather than to invest in the firm's activities such as translating business opportunities into a new product or business process. In contrast, human resource slack illustrates a strong positive impact on all mentioned innovation types in the data analysis, meaning that firms experiencing human resource slack are more likely to introduce new products, make improvements to the current product, and to engage in a new technology/production process. Unlike the financial slack, the human resource slack is more fixed in firms (Voss et al., 2008). Workers employed by firms have specific knowledge and skills to meet the requirements of the firm's business activities, which means that it is not easy for owners/managers to relocate this type of slack to family activities rather than to the firm. Consequently, owners/managers are more likely to deploy that underemployed resource to meet the demands of new business opportunities that lead to the introduction of innovation. 
The results also illustrate that the impact of financial slack resources on innovation is also influenced by the institutional context, where a higher level of business favourability causes smaller negative impact on incremental product and process innovation. One possible explanation for this fact may be, that the firms operating in better business circumstances usually have more business opportunities, including the expansion into a new market. Thus, it is easier for them to make use of resource slack for their production compared to those firms operating in more difficult business circumstances. Considering the fact that financial shortage is usually the biggest constraint for SME development (CIEM et al. 2016), this finding may imply that improvement of business conditions should suggest a better use of financial slack for SME innovation in Viet Nam. More importantly, the presence of high levels of institutions associated with the development of the financial market expedites the access to financial sources, thus giving firm owners more choice in sustaining their family's financial capabilities instead of using financial slack. On the other hand, financial slack now can be used to serve the demands of growth of firms, resulting in the induction of new products or technologies.

In the case of human resource slack and its impact on innovation, the findings show that operating in more favourable business environment does not enhance the impact. In contrast, it reduces the positive effect of human resource slack on innovation. One possible explanation for this unexpected consequence is the employee turnover. The high level of development of labour market in favourable business environment allows the excessive employee easier to move to other firms. This employee movement creates a loss in human capital and knowledge of firms (Eriksson et al., 2014). Though firms might have chance in exploring business opportunities in a favourable business environment, the presence of a loss of knowledge does not at least allow firms to transfer these business opportunities into real new product or business process. Consequently, it reduces the impact of human resource slack on innovation. .

As expected, firms operating in higher level of technology industries are more likely to innovation than those in low technology counterparts in terms of introducing new products and improving existing products. However, the results do not show the significant difference amongst three considered levels of technology industries regarding to the process innovation. In addition, the results also strongly indicate that larger firms are more likely to engage in innovation than smaller firms at all three types of innovation. Finally, informal firms (household businesses) are less likely to engage in innovation probability than formal firms.

\section{Conclusions}

In this paper, the study deepens the understanding of the role of slack resources in promoting innovation. By exploring a dataset from the Vietnamese SMEs survey, the study offers a number of theoretical and managerial contributions. First, the research expands the boundary conditions of the impact of slack resources on family business innovation. This contributes to the explanation for the different impact of slack resource types on innovation. While in public firms, there is a clear line between firms and owners'/managers' family operational activities, the blurred line in family business together with the stewardship role motivates owners to direct the underemployed resource to first guarantee their family benefits (Donaldson and Davis, 1991; 1993). This leads to the negative consequence of slack on innovation. This is more pronounced for slack resources that are less fixed such as financial slack. Meanwhile, for more fixed slack, the owners have no other choices but to invest in firm's activities, thus explaining the positive effect.

Second, the study sheds light on the relationship between slack resources and innovation through the influence of institutional context in emerging economies. The findings show that slack does not work in isolation in supporting innovation. It requires an interaction with other external factors embedded in the institutions. The constitution of business environment conditions thereby can hinder or 
facilitate the impact of slack on innovation. In other words, it further confirms the orchestra of resources in sustaining growth and competitive advantages.

The findings also suggest a number of managerial and economic policy implications. First, a clear direction in the deployment of different slack resource types is crucial for the introduction of a new product or business process. While financial slack is fungible across inner and outer business activities, the high levels of that type of slack may not always be associated with innovation. Meanwhile, the more fixed human resource slack is an important source of innovation support. Second, ensuring the retention of human resources is supportive for the impact of human resource slack on innovation. Third, the findings suggest that the facilitation of the business environment, such as developing financial markets, will motivate firms to more fully deploy their slack resources.

Although our study has advanced the understanding of the role of slack resources on innovation, it is important to highlight some limitations. First, we are unable to create continuous variables for innovation, thus the possibility of measurement bias exists. We reduced the likelihood of that error by testing the regressions with an assumed substitute variable of a continuous innovation slack resource change level. The consistent results indicate a high degree of robustness.

\section{References}

Acs, Z.J. and Audretsch, D.B. (1988). 'Innovation and firm size in manufacturing'. Technovation, 7, 197210.

Acs, Z.J. and D.B. Audretsch. (1990), Innovation and Small Firms. Cambridge, MA: MIT Press.

Acs, Z.J. and Audretsch, D.B. (1993). Small Firms and Entrepreneurship: An East-West Perspective. Cambridge: Cambridge University Press.

Agarwal, S., Erramilli, M.K., and Dev, C.S. (2003). 'Market orientation and performance in service firms: role of innovation'. Journal of Service Marketing, 17(1), 68-82.

Ang. S., and Straub, D.W. (1998). 'Production and transaction economics in information systems outsourcing: A study of the U.S. banking industry'. MIS Quarterly, 22(4), 535-552.

Anh, N.T.T, Luu., M.D., and Trinh, D.C. (2014). 'The evolution of Vietnamese industry'. WIDER Working Paper 76/2014. Helsinki: UNU-WIDER.

Armstrong, J. S., and Overton, T. S. (1977). 'Estimating non-response bias in mail surveys'. Journal of Marketing Research, 14, 396-402.

Bauchet, J., and Morduch, J. (2013). 'Is Micro too Small? Microcredit vs. SME Finance'. World Development, 3, 288-297.

Baumol, W. (1990). 'Entrepreneurship: productive, unproductive and destructive'. Journal of Political Economy, 98, 893-921.

Beck, T., Demirgüç-Kunt, A., and Levine, R. (2005). 'SMEs, Growth and Poverty: Cross-Country Evidence'. Journal of Economic Growth, 10, 197-227.

Bizzi, L. (2017). 'The strategic role of financial slack on alliance formation'. Management Decision, 55(2), 383-399.

Brown, J., Martinsson, G., and Petersen, B. (2012). 'Laws, stock markets, and innovation'. Journal of Finance, 68, 1517-1549.

Bogers, M., Afuah, A., and Bastian, B. (2010). 'Users as Innovators: A Review, Critique, and Future Research Directions'. Journal of Management, 36(4) 857-875. 
Bourgeois L.J. III. (1981). 'On the measurement of organizational slack'. Academy of Management Review, 6, 29-40

Capaldo, G., Iandoli, L., Raffa, M., and Zollo, G. (2003). ’The Evaluation of Innovation Capabilities in Small Software Firms: A Methodological Approach'. Small Business Economics, 21, 343-354.

Cefis, E., and Marsili, O. (2006). 'Survivor: the role of innovation in firm's survival'. Research Policy, 35, 626-641.

Chang, S., Jaw, Y., and Chiu, H. (2012). 'A Behavioral Perspective of International New Ventures: Slack, Early Internationalization, and Performance'. The Journal of Global Business Management, 8 (2), 200-211.

Child. J. (1972). 'Organizational structure, environment, and performance: The role of strategic choice'. Sociology, 6(1), 1-22.

CIEM. (2007). Characteristics of the Vietnamese business environment: Evidence from a SME survey in 2005. Hanoi: Labour and Social Affairs Publishing House.

CIEM, DoE, ILSSA and UNU-WIDER (2016). 'Characteristics of the Vietnamese Business Environment: Evidence from a SME Survey in 2015'. Available at: https://www.wider.unu.edu/sites/default/files/SME2015-report-English.pdf (accessed on 10 January 2018).

Cohen, W.M., March, J.G. and Olsen, J.P. (1972). 'A garbage can model of organizational choice'. Administrative Science Quarterly, 17(1), 1-25.

Corbetta, G., and Salvato, C. (2004). 'Self-serving or self-actualizing? Models of man and agency costs in different types of family firms: A commentary on Comparing the agency costs of family and non-family firms: Conceptual issues and exploratory evidence'. Entrepreneurship Theory and Practice, 28(4), 355-362.

Cunningham, L.X. (2011). 'SMEs as motor of growth: a review of China's SMEs development in thirty years (1978-2008)'. Human Systems Management, 30(1), 39-54

Cyert, R.M, Feigenbaum, E.A, and March, J.G. (1959). 'Models in a behavioral theory of the firm'. Behavioral Science, 4(2), 81-95.

Cyert, R.M., and March, J.G. (1963). A Behavioral Theory of the Firm, Englewood Cliffs: Prentice Hall.

Damanpour, F. (1991). 'Organizational innovation: a meta-analysis of effect of determinants and moderators'. Academy Management Journal, 34(3), 555-590.

Davis, J.H., Schoorman, F.D., and Donaldson, L. (1997). 'Toward a stewardship theory of Management'. Academy of Management Review, 22, 20-47.

De Jong, J. P. J., and Vermeulen, P. A. M. (2004). Determinants of product innovation in small firms: A comparison across industries. Zoetermeer, Netherlands: Scientific Analysis of Entrepreneurship and SMEs.

Donaldson, L., and Davis, J. H. (1991). 'Stewardship Theory or Agency Theory: CEO governance and shareholder returns'. Australian Journal of Management, 16, 49-65.

Donaldson, L., and Davis, J. H. (1993). 'The Need for Theoretical Coherence and Intellectual Rigour in Corporate Governance Research: Reply to Critics of Donaldson and Davis'. Australian Journal of Management, 18, 213-225.

Eriksson, T., Qin, Z., and Wang, W. (2014). 'Firm-level innovation activity, employee turnover and HRM practices - Evidence from Chinese firms'. China Economic Review, 30, 583-597.

Fama, E.F. (1980). 'Agency problems and theory of the firm'. Journal of Political Economy, 88 (2), 288307. 
Freeman, C. (1982). The Economics of Industrial Innovation, (2nd ed.), London: Frances Printer.

Geiger, S.W., and Cashen, L.H. (2002). 'A multidimensional examination of slack and its impact on innovation'. Journal of Management Issues, XIV(I), 68-84.

George, G. (2005). 'Slack resources and the performance of privately held firms'. Academy of Management Journal, 48, 661-676

Gomez-Mejia, L.R., Haynes, K., Nuñez-Nickel, M., Jacobson, K.J.L., and Moyano-Fuentes, J. (2007). 'Socioemotional wealth and business risks in family-controlled firms: Evidence from Spanish olive oil mills'. Administrative Science Quarterly, 52, 106-137.

Greve, H. (2003). 'A Behavioral Theory of RandD Expenditures and Innovations: Evidence from Shipbuilding'. Academy of Management Joumal. 46, 685-702.

GSO (2017). Statistical Year Book. Hanoi: Statistical Publishing House.

Hadjimanolis, A. (1999). 'Barriers to Innovation for SME in a Small Less Developed Country (Cyprus)'. Technovation, 19, 561-570.

Hall, B. and Rosenberg, N. (2010). Handbook of Economics of Innovation, vol. 1. Amsterdam: NorthHolland.

Hall, B.H., Lotti, F., and Mairesse, J. (2009). 'Innovation and productivity in SMEs: Empirical evidence for Italy'. Small Business Economics, 33(1), 13-33

Hausman, A., and Johnston,W.J. (2014). 'The role of innovation in driving the economy: Lessons from the global financial crisis'. Journal of Business Research, 67(1), 2720-2726.

Hogan, S.J., Soutar, G.N., McColl-Kennedy, J.R., and Sweeney, J.C. (2011). 'Reconceptualizing professional service firm innovation capability: Scale development'. Industrial Marketing Management, 40(8), 1264-1273.

Honjo, Y., and Harada, N. (2006). 'SME policy, financial structure and firm growth: Evidence from Japan'. Small Business Economics, 27, 289-300.

Hsu, P., Tian, X., and Xu. Y. (2014). 'Financial Market Development and Innovation: Cross Country Evidence'. Journal of Financial Economics, 112, 116-135.

ILO (2016). Key Indicators of the Labour Market, (Ninth edition). Geneva: International Labour Office.

Katila, R., and Shane S. (2005). 'When does the lack of resources make new firms innovative?' Academy Management Journal, 48(5), 814-829.

Madrid-Guijarro, A., Garcia, D., and Van Auken, H. (2009). 'Barriers to Innovation among Spanish Manufacturing SMEs'. Journal of Small Business Management, 47(4), 465-488.

Malesky, E. (2017). The Viet Nam Provincial Competitiveness Index: Measuring Economic Governance for Private Sector Development, 2016. Final Report. Ha Noi: Viet Nam Chamber of Commerce and Industry and United States Agency for International Development.

Marlin, D.R. and Geiger, S. (2015). 'A reexamination of the organizational slack and innovation relationship'. Journal of Business Research, 68(12), 2683-2690.

Mazzarol, T. (2014). Growing and sustaining entrepreneurial ecosystems: What they are and the role of government policy, White Paper WP01-2014. Fremantle: Small Enterprise Association of Australia and New Zealand (SEAANZ), www.seaanz.org.

Mel, S.D., McKenzie, D., and Woodruff, C. (2009). 'Innovative firms or innovative owners? Determinants of innovation in micro, small, and medium enterprises'. Policy Research Working Paper No. WPS4934. Washington, DC: The World Bank.

Mishina, Y., Pollock, T.G., and Porac. J.F. (2004). 'Are more resources always better for growth? Resource stickiness in market and product expansion'. Strategic Management Journal, 25, 1179-1197. 
Nason, R.S., and Wiklund, J. (2015). 'An assessment of resource-based theorizing on firm growth and suggestions for the future'. Journal of Management, 20(10), 1-29.

Natividad, G. (2013). 'Financial slack, strategy, and competition in movie distribution'. Organization Science, 24(3), 846-864.

Nee, V. (1996). 'The Emergence of a Market Society: Changing Mechanisms of Stratification in China'. The American Journal of Sociology, 101, 908-949.

Ngo, L.V. and O'Cass, A. (2009). 'Creating Value Offerings via Operant Resource-Based Capabilities'. Industrial Marketing Management, 38(1), 45-49.

Nohria, N., and Gulati, R. (1996). 'Is slack good or bad for innovation?' Academy of Management Journal, 39(5), 1245-1264.

Nohria, N., and Gulati, R. (1997). 'What is the optimum amount of organizational slack?' European Management Journal, 15, 603-611.

North, D. C. (1991). 'Institutions'. Journal of Economic Perspectives, 5(1), 97-112.

OECD (2000). 'Small and Medium-sized Enterprises: Local Strength, Global Reach'. OECD Policy Brief, June 2000. Paris: OECD.

OECD (2005). Proposed Guidelines for Collecting and Interpreting Innovation Data: Oslo Manual. Paris: OECD Publishing.

OECD (2009). OECD Science, Technology and Industry Scoreboard 2009, Paris: OECD Publishing.

OECD (2010). Measuring Innovation: a new perspective, Paris: OECD Publishing.

Pannucci, C.J., and Wilkins, E.G. (2010). 'Identifying and avoiding bias in research'. Plastic and Reconstructive Surgery, 126(2), 619-625.

Parida, V., and Örtqvist, D. (2015). 'Interactive effects of network capability, ICT capability, and financial slack on technology-based small firm innovation performance'. Journal of Small Business Management, 53(S1), 278-298.

Penrose, E.T. (1959). The Theory of the Growth of the Firm. Oxford: Oxford University Press.

Peters, B., Roberts, M.J., Vuong, V.A. and Fryges, H. (2017). 'Estimating dynamic R\&D choice: an analysis of costs and long-run benefits'. The R\&D Journal of Economics, 48, 409-437.

Pitelis, C.N. (2007). 'A Behavioral Resource-Based View of the Firm: the Synergy of Cyert and March (1963) and Penrose (1959)'. Organization Science, 18(3), 478-90.

Podsakoff, P.M., MacKenzie, S.B., Lee, J-B., and Podsakoff, N.P. (2003). 'Common method biases in behavioral research: A critical review of the literature and recommended remedies'. Journal of Applied Psychology, 88, 879-903.

Romijn, H. and Albaladejo, M. (2002). 'Determinants of innovation capability in small electronics and software firms in southeast England'. Research Policy, 31(7): 1053-1067.

Sandberg, B., and Aarikka-Stenroos, L. (2014). 'What makes it so difficult? A systematic review on barriers to radical innovation'. Industrial Marketing Management, 43(8), 1293-1305.

Schumpeter, J.A (1939). Business Cycles. New York: McGraw-Hill.

Scott, W.R. (1995). Institutions and Organizations. Thousand Oaks, CA: Sage.

Singh, J. (1986). 'Performance, slack, and risk taking in organizational decision making'. Academy of Management Journal, 29, 562-585.

Smallbone, D., and Welter, F. (2001). 'The Role of Government in SME Development in Transition Economies'. International Small Business Journal, 19, 63-77. 
Slater, S.F., Mohr, J.J., and Sengupta, S. (2014). 'Radical product innovation capability: literature review, synthesis, and illustrative research propositions'. Journal of Product Innovation Management, 31(3), 552-566.

Storey, D.J., (1994). Understanding the Small Business Sector. London: Thomson Learning.

Tan, J., and Peng, M.W. (2003). 'Organizational Slack and Firm Performance During Economic Transitions: Two Studies from An Emerging Economy'. Strategic Management Journal, 24, 1249 1263.

Vanacker, T., Collewaert, V., and Zahra, S.A. (2017). 'Slack resources, firm performance, and the institutional context: Evidence from privately held European firms'. Strategic Management Journal, 38(6), 1305-1326.

Voss, G.B., Sirdeshmukh, D., and Voss, Z.G. (2008). 'The effects of slack resources and environmental threat on product exploration and exploitation'. Academy of Management Journal, 51(1), 147-164.

Wang, C. (2013). 'Can institutions explain cross country differences in innovative activity?'. Journal of Macroeconomics, 37, 128-145.

Wang, H., Choi, J., Wan, G., and Dong, J. Q. (2016). 'Slack resources and the rent-generating potential of firm-specific knowledge'. Journal of Management, 42(2), 500-523.

Welbourne, T.M., Johnson, D.E., and Erez, A. (1998). 'The role-based performance scale: Validity analysis of a theory-based measure'. Academy of Management Journal, 41, 540-555.

Williamson, O.E. (1963). 'Managerial discretion and business behaviour'. American Economic Review, 53, 1032-1057.

Williamson, O.E. (2005). 'Transaction cost economics. In C. Menard and M.M. Shirley (eds.), Handbook of New Institutional Economics, 41-46. Netherlands: Springer.

Wooldridge, J. (2010). Econometric Analysis of Cross Section and Panel Data. Cambridge, MA: MIT Press

World Bank. (2013). World Development Report 2014: Risk and Opportunity-Managing Risk for Development. Washington, DC: World Bank

Yanadori, Y., and Cui, V. (2013) 'Creating incentives for innovation? The relationship between pay dispersion in R\&D groups and firm innovation performance'. Strategic Management Journal, 34(12), 1502-1511. 